\title{
BIEDRĪBU KULTŪRA UN LATVIEŠU GRĀMATNIECİBA KURZEMĒ UN VIDZEMĒ 19. GADSIMTA SĀKUMĀ
}

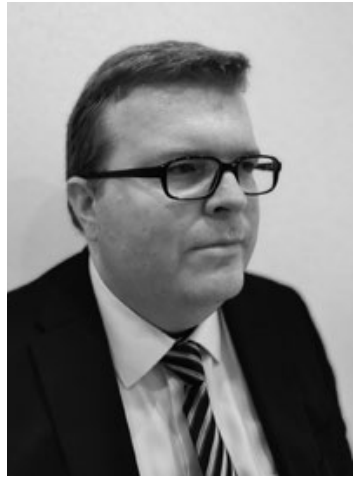

Pauls Daija ir Dr. philol., literatūrzinātnieks, Latvijas Zinātṇu akadēmijas korespondētājloceklis, vadošais pētnieks Latvijas Universitātes Literatūras, folkloras un mākslas institūtā un Latvijas Nacionālajā bibliotēkā. Viṇa pētnieciskās intereses ietver vācbaltiešu kultūras vēsturi, latviešu literatūras un grāmatniecības vēsturi 18. gadsimta otrajā pusē un 19. gadsimta sākumā, hernhūtiešu rokraksta literatūru. Publicējis monogrāfijas Apgaismība un kultūrpārnese, Latviešu laicīgās literatūras tapšana (2013) un Literary History and Popular Enlightenment in Latvian Culture (2017), sastādījis vairākus pētniecisko rakstu krājumus un tulkojis zinātnisko literatūru.

Raksturvārdi: apgaismība, latviešu grāmatniecība, biedrības, vācbaltieši, filantropisms.

\section{Ievads}

No 16. gadsimta lìdz pat 19. gadsimta vidum latviešu grāmatniecības galvenie veidotāji bija vācbaltiešu literātu kārtas pārstāvji, galvenokārt luterāṇu mācītāji. Tādējādi arī latviešu modernās daiḷliteratūras, kā arī profesionāli tehniskās literatūras sākumi 18. gadsimta vidū un otrajā pusē, kuru veidošanās bija saistīta ar apgaismības idejām, tapa, pateicoties vācbaltiešu literātu iniciatīvai. Tā bija individuālos apsvērumos balstīta un decentralizēta - neeksistēja vienots apgaismïbas projekts vai apgaismotāju grupa. 19. gadsimta sākumā un pirmajā pusē, savukārt, latviešu grāmatniecībā aizvien lielāku nozīmi ieguva biedrošanās un centralizēta iniciatīva. Šis process atbalsoja radniecīgas norises Rietumeiropā, īpaši vācvalodīgajā kultūrtelpā. Baltijā veidojās dažādas patriotiskas un profesionālas biedrības, un vairākām no tām bija būtiska nozīme latviešu literatūras veicināšanā. To tapšana bija saistīta ar dažiem faktoriem - gan Lielās franču revolūcijas un Napoleona karu, kā arī Aleksandra I ìstenoto liberālo reformu inspirēto brīvo atmosfēru Vidzemē un Kurzemē, gan brīvmūrnieku ložu aizliegumu, kas lika meklēt jaunas legālas pulcēšanās formas, ${ }^{1}$ gan arī literātu kārtas nostabilizēšanos un nepieciešamību pēc ideju apmainas foruma. Liela nozìme tam, ka biedrības pievērsās latviešu izglītošanai caur grāmatām, bija dzimtbūšanas atcelšanai Kurzemē 1817. gadā un Vidzemē 1819. gadā. Biedrības ar brīvprātības principu veidoja alternatīvu sabiedriskām reformām "no augšas", vienlaikus liekot pamatus demokrātiskas sabiedrības principu nostiprināšanai, modernās pilsoniskās sabiedrības vērtību attīstībai. ${ }^{2}$

Sekojot Baltijas apgaismības ideju šķīrumam radikālajā un mērenajā spārnā, kura atskaites punkts ir attieksme pret dzimtbūšanas atcelšanu, patriotisko biedrību aktivitātes lielākoties pieskaitāmas mērenajai apgaismībai. Līdzịgi šāda tipa biedrībām vācvalodīgajā kultūrtelpā tās bija vērstas nevis uz revolucionāriem pārveidojumiem, bet uz reformām pastāvošā sistēmā. ${ }^{3}$ Latviešu grāmatniecības vei-

\footnotetext{
1 Stradiṇš 2009, 365-366, 390; Pīrāgs 2008, 68-79.

2 Hackmann 2012, 11.

3 Reinalter 1995, 158-160; Kopitzsch 2003, 139-149.
} 
cināšana piederēja pie šāda tipa reformām. Šì raksta mērḳis ir aplūkot un analizēt vācbaltiešu biedrību ieguldījumu latviešu grāmatniecībā 19. gadsimta pirmajās desmitgadēs, pievēršoties grāmatu izdošanai un izplatǐšanai, kā arī diskusijām par latviešu izglìtību.

\section{Vidzemes Vispārderīgā un ekonomiskā biedrība}

1792. gadā dibinātā un 1795. gadā valdības apstiprinātā Vidzemes Vispārderīgā un ekonomiskā biedrība (Kaiserliche Livländische Gemeinnützige und Öconomische Societät, turpmāk - VVEB) pulcēja galvenokārt muižniekus, kuri bija ieinteresēti lauksaimniecības reformās. Runa bija par 18. gadsimta agrārajiem jauninājumiem, piem., kartupel̦u un āboliṇa kultivēšanu, daudzlauku sistēmu, augsnes rotāciju, modernāku tehniku. Tāpat biedrības plānos ietilpa zināšanu izplatīšana par lauksaimniecības jautājumiem, lauksaimniecības izstrādājumu transporta organizēšana, fabriku un manufaktūru attīstības veicināšana. ${ }^{4}$ Apgaismības laikmetā šo jauninājumu, kuri saistīti arī ar dabaszinātṇu atklājumiem, kontekstu veidoja franču fiziokrātu kustỉba - tā atzina zemnieku kārtas nozīmi sabiedrībā un inspirēja vācvalodīgās tautas apgaismības centienus izglītot zemniekus jaunākajās lauksaimniecības metodēs, ar laiku arī - būtiski mainìt zemnieku mentalitāti, padarot tos mazāk atkarīgus no tradīcijām un veicinot atvērtību jaunajam. 18. un 19. gadsimta mijā agrārās reformas galvenokārt bija muižnieku nodarbošanās, kamēr dzimtbūšanā esošie zemnieki gan tradicionālisma, gan ierobežoto resursu dẹl turpināja saimniekot saskaṇā ar metodēm, kas pārmantotas no iepriekšējām paaudzēm. Tas veda pie pieaugošas nabadzības, arī aizvien biežākiem neražas un bada gadiem.

Biedrības mērḳu formulēšanā būtiska nozīme bija zinātnieka, biedrības sekretāra (1795-1802), vēlākā Tērbatas Universitātes rektora Georga Frīdriha Parrota (Georg Friedrich Parrot, 1767-1852) idejām, kuras atbalstīja arī Vidzemes generālsuperintendents Karls Gotlobs Zontāgs (Karl Gottlob Sonntag,

\footnotetext{
4 Engelhardt, Neuschäffer 1983, 9-39; Strods
} 1962, 7-110.
1765-1827). Akcentējot iepriekš minētos apsvērumus, kuru dẹl nepieciešams uzlabot lauksaimniecības situāciju, Parrots uzsvēra nepieciešamību sniegt dažāda veida palīdzību zemniekiem un vērsties pie tiem ar iespiesto mediju starpniecību, biedrības darbībā neaprobežojoties tikai ar "lauksaimniecības un pilsētu produktiem", bet arī sniedzot "dvēseles produktus". ${ }^{5}$

Jau 18. gadsimta 90. gados VVEB katrā draudzē bez maksas izdalīja latviešu lauksaimniecības izdevumus. ${ }^{6}$ Ar laiku biedrība sāka publicēt pati savus izdevumus. 1800. gadā nāca klajā VVEB biedra ārsta Johana Heinriha Dirzena (Johann Heinrich Dyrsen, 1770-1804) Glābšanas un palīdzības grāmata, kas rāda, kā tos cilvēkus, kas ātrumā pamiruši ir, pie dzīvības var izglābt un ka arīdzan iekš citām neveselības klūtām [kḷūdām - P. D.] var palīdzèt un Johana Justīna Lopenoves (Johann Justin Loppenowe, 1741-1818) un Oto Frīdriha Paula Rīla (Otto Friedrich Paul Rühl, 1764-1835) brošūra Sarunāšanas starp diviem latviskiem zemniek[i]em Bērze un Kalniṇ. Populārmedicīnisko tekstu par dzīvības glābšanu biedrība laida klajā arī igauṇu valodā, daḷu eksemplāru paredzot izvietot bez maksas krogos; savukārt dialoga formā sarakstītie lauksaimniecības padomi bija bezmaksas pielikums Vidzemes kalendāram un tulkoti pēc Georga Frīdriha Parrota apcerējuma VVEB periodiskajā izdevumā Verhandlungen der livländischen gemeinnützigen und ökonomischen Sozietät. Grāmatā bija sniegtas vispārīgas atziṇas par lauksaimniecības jauninājumu izmantošanas priekšrocībām, kā arī konkrēti padomi kartupeḷu, kāpostu, apiṇu u. c. lauksaimniecības kultūru kultivēšanā. "Trūkst ziņu, vai šie ieteikumi ir īstenoti zemnieku sētās," norāda Jānis Stradinšs, "taču lasītāju praktisko apvārsni tie varētu būt paplašinājuši." " Tieši šajā aspektā - lasītāju redzesloka paplašināšanā - meklējama šĩs un citu biedrību izdoto darbu nozìme.

Turklāt biedrība izsolìja prēmijas un goda rakstus zemniekiem, kas savā praktiskajā darbībā ieviesa lauksaimniecības jauninājumus.

\footnotetext{
5 Citēts pēc: Stradinšs 2009, 314.

6 Apīnis 1991, 114.

7 Stradin̦š 2009, 318.
} 
Te minams 1805. gadā publicētais uzsaukums Jaunas algas, kas Vidzemes zemniekiem top solìtas - tajā sniegtas augsnes uzlabošanas instrukcijas un informācija par prēmijām un goda rakstiem, kas piešķirami labākajiem zemniekiem. Publicēti arī saraksti ar apbalvotajiem zemniekiem. ${ }^{8}$ Tāpat arī 1815. gadā nāca klajā Ziņa priekš visiem vidzemniekiem, kurā izklāstīts VVEB aicinājums sēt miežus, paziņojums par prēmijām, padomi koku sēklu savākšanā, mežu stādīšanā. ${ }^{9}$

1817. gadā biedrība izdeva Jaunu labu zinu un padomu grāmatu, kuru rediǵēja un papildināja Mālpils mācītājs Johans Gotfrīds Ageluts (Johann Gottfried Ageluth, 1763-1848), ievietodams no jauna sacerētus lauksaimniecības padomus un pielāgodams darbā izklāstītās atziṇas brīvajiem zemniekiem apstākḷ os pēc dzimtbūšanas atcelšanas. ${ }^{10}$ Šis darbs bija izcilākās 18. gadsimta beigu lauksaimniecību rokasgrāmatas Labu ziņu un padomu grāmata (1791) pārstrādājums. To bija veidojuši Liborijs Bergmanis (Liborius Bergmann, 1754-1823), Gotlibs Šlēgelis (Gottlieb Schlegel 1739-1810), Ludvigs Augusts Mellīns (Ludwig August Mellin, 1754-1835) un Gustavs Bergmanis (Gustav Bergmann, 1749-1814), un šo darbu var uzskatīt par pirmo lauksaimniecības un medicinas enciklopēdiju zemniekiem, tā tapusi pēc vācvalodīgās tautas apgaismìbas ievērojamākā darba un dižpārdokḷa - Rūdolfa Cahariasa Bekera (Rudolph Zacharias Becker, 1752-1822) Noth- und Hülfsbüchlein [Vajadzības un palīdzības grāmatiṇa] (1788) parauga. VVEB turpināja šo enciklopēdisko ievirzi zemnieku apgaismošanā.

Savukārt 1831. gadā biedrība izdeva grāmatu par merīnaitu kopšanu İsa pamācīšana, no kuras aitu meisteri un gani var mācīties, $k \bar{a}$ merino aitas jāapkopj, kas bija gadagrāmatā Livländisches Jahrbuch der Landwirtschaft ievietotā apcerējuma Schäfer-Büchlein aus Schmalzen's und Koppe's Anleitung für inländische Schäfer und Schäfer-Knechte tulkojums. Šis pats apcerējums nāca klajā arī abos igauņu dialektos. Arī šīs grāmatas klajā nākšana bija saistīta ar aktuālajiem lauksaimniecỉbas

\footnotetext{
8 Šiško 1999, 254-246.

9 Turpat, 288.

10 Daija 2016, 84-100.
}

jauninājumiem. Heinrihs Strods norāda: “Ap 1824. g. sākās plaša merīnas aitu audzēšanas pieredzes studēšana Vācijā un propaganda Latvijā. Ievērojama nozīme Vidzemes muižnieku iepazīstināšanā ar merīnas aitkopību bija sakšu aitkopim M. Špekem, kas Latvijā nolasīja lekcijas, piesūtīja materiālus par aitkopību un organizēja merīnas aitu ganāmpulku iepirkšanu Saksijā." ${ }^{11}$ Šādi biedrība, reageejot uz aktualitātēm lauksaimniecībā un medicīnā, veicināja latviešu praktiski ekonomiskās grāmatniecības attīstību, izkopjot specializētus literatūras žanrus.

\section{Rīgas Literāri praktiskā pilsoṇu savieniba}

Radniecīga ievirze bija Rīgas Literāri praktiskajai pilsoṇu savienībai (LiterärischPraktische Bürgerverbindung zu Riga, turpmāk - RLPPS), kas dibināta 1802. gadā, sekojot Hamburgas Patriotiskās biedrības paraugam. ${ }^{12}$ Tās dibinātāji bija mācītāji Liborijs Bergmanis, Johans Augusts Albanuss (Johann August Albanus, 1765-1839) un Karls Gotlobs Zontāgs, ar laiku biedrībā iestājās ḳīmiḳis Dāvids Hieronims Grindelis (David Hieronymus Grindel, 1776-1836), arhitekts Kristofs Hāberlands (Christoph Haberland, 1750-1803), dendrologs un vairāku latviešu dārzkopības grāmatu autors Johans Hermanis Cigra (Johann Hermann Zigra, 1775-1857), par goda biedru kḷuva kultūrvēsturnieks Johans Kristofs Broce (Johann Christoph Brotze, 1742-1823). Par savu mērḳi biedrība izvirzīja vispārderīgu zināšanu izplatīšanu, sekmējot garīgo ideju izmantošanu ikdienas dzivēe un teorijas un prakses saikni. Biedrība orientējās uz morāli, medicīnu, poēziju, tirdzniecību, lauksaimniecību, vēsturi, geogrāfiju, ārpusē atstājot teologiju, jurisprudenci un politiku. ${ }^{13}$ Sākotnēji tā veidojās kā ideju forums, kurā priekšlasījumu un sākumā slēgtu, vēlāk atklātu sēžu formā tika spriests par nepieciešamajām reformām galvenokārt filantropisma perspektīvā un Rīgas nabadzīgo iedzīvotāju dzīves līmeña uzlabošanā. Biedrībai bija cieši sakari ar ārzemju

\footnotetext{
11 Strods 1972, 166.

12 Hollander 1927, 2.

13 Bulmerincq 1852, 2.
} 
biedrībām, akadēmijām, organizācijām, tāpēc bieži vien praktiski pasākumi tika īstenoti, vispirms apgūstot cittautu pieredzi un referējot par to biedrības sēdēs. ${ }^{14}$ Biedrības pamatā ir izpratne par "cilvēkiem, kas vēlas darboties priekš citiem". ${ }^{15}$ Statūtos norādīts, ka biedrībai "nav cita mērḳa kā izplatīt vispārderīgas zināšanas .. līdzpilsoṇu vidū [..]. Ar šādu mērḳi tā darbojas nevis priekš zinātniekiem pašiem, arī tās plānos nav darboties zinātnē tieši, bet tā tikai vēlas katru cilvēku zināšanu, domāšanas un izgudrošanas rezultātu izplatīt uz praktisko un pilsonisko dzivi”. ${ }^{16}$

Biedrības aktivitātes galvenokārt bija saistìtas nevis ar lauksaimniecību, bet ar Rìgas sabiedrisko apstākḷu uzlabošanu, izstrādājot priekšlikumus tādiem jautājumiem kā sociālā higiēna, ielu apgaismojums, ùdensapgāde, kurināmā apgāde, krājkasu un zupas virtuvju organizēšana. ${ }^{17}$ Līdzās šiem tehniskajiem jautājumiem biedrība veica nozīmīgu ieguldījumu Rīgas vēstures izpētē, ${ }^{18}$ no 1810 . gada sāka izdot laikrakstu Rigaische Stadtblätter, kas kḷuva par vienu no nozīmīgākajiem Rīgas periodiskajiem izdevumiem. Biedrības redzeslokā bija nabadzīgo iedzīvotāju un bāreṇu izglìtības jautājumi, 1817. gadā tā dibināja Lutera skolu Rīgā. ${ }^{19}$ Visu šo daudzveidīgo aktivitāšu lokā bija arī iespiesto izdevumu publicēšana latviešu valodā.

Latviešu valodā biedrība izdeva vairākus populārmedicīniskus darbus par dzīvības glābšanu - ārsta un tiesu padomnieka Joahima Ramma (Johann Ramm, 1763-1825) Mācību, kā tādiem, kas ūdenī ir slīkuši, to dzīivību var gläbt un atkal pamodit (1811), Karla Vilperta (Karl Wilpert, 1778-1839) darba Anleitung zur Rettung derer, die im Wasser verunglückt sind. Anleitung zur Rettung der Erfrorenen latviešu tulkojumu Mācība, kā tos var glābt, kas ir noslīkuši ūdenī. Mācība, kā tos var glābt, kas ir nosaluši (abi 1816), Frīdriha Kristofa Štrāzena (Friedrich Christoph Strahsen, 1781-1859)

\footnotetext{
14 Bulmerincq 1852, 2.

15 Turpat, 6.

16 Hollander 1927, 30; citēts pēc: Stradiņš 2009, 390-391.

17 Bulmerincq 1852, 15-21.

18 Stradiņš 2009, 392.

19 Bulmerincq 1852, 7.
}

aprakstu ar pamācībām par pirmās palīdzỉbas sniegšanu nelaimes gadijumos (1826). Daļa no šo darbu metiena bija iecerēta bezmaksas izdalīšanai, savukārt 1826. gada izdevums bija paredzēts plakāta veidā piestiprināšanai publiskās vietās.

19. gadsimta 20. gados pēc Berlines parauga biedrība sekmēja arī idejas par naudas noguldī̌sanu uz procentiem, nodibinot krājkasi un publicējot tās statūtus arī latviešu valodā. Konceptuāli formulēta šīs iniciatīvas ideja: "Gan ties: mūsu pilsētā ir gādāts, ka nabadziņš, kas caur sērdzību jeb vecumu savu maizìti vairs nevar pelnīt, dabū, ar ko var pārtikt; ka nabags slimnieks vietu atron, kur tiek kopts un ārstēts; ka nabags bāriņš top uzturēts un audzināts; bet par to vēl nav gādāts, ka nabadziņš savu pāripalikšu krātu rubel̦u jebkur var nodot, kur tas labi ir glabāts, ka to neizdod pavelti jeb caur viltiniekiem nepamet. Cik labi nabadziņam klātos, ja tam arī naudas sauja būtu, kas jo gadus, jo vairāk vairotos!"20

19. gadsimta 30. gados, Baltijā aizvien populārākām kḷūstot atturības idejām, biedrība centās sekmēt atturības biedrību izveidi, šajā nolūkā 1837. gadā izdodot latviešu valodā Augusta Dēbnera (August Döbner, 18001873) darbu Zinas par sātības biedrībām. Šì izdevuma 500 eksemplāru izdalīi mācītājiem tālākizplatīšanai zemniekiem, un tas "popularitātes ziṇā palika nepārspēts citu 19. gs. pirmās puses pretalkoholisma grāmatu vidū". ${ }^{21}$ Tam sekoja šveiciešu apgaismotāja Heinriha Čokes (Heinrich Zschokke, 1771-1848) stāsta Die Branntweinpest (1837) tulkojums latviešu valodā Stāsts, kas atbild uz tiem Zālamana vārdiem (1838). Šie darbi uzskatāmi par pirmajiem pretalkohola sacerējumiem latviešu literatūrā, kas, izmantojot vācu paraugus, lika pamatus atturības rakstniecības tradīcijai. ${ }^{22}$

Tāpat kā VVEB, arī RLPPS literārajā darbībā redzams, ka pievēršanās latviešu uzrunāšanai un latviešu grāmatniecībai bija saistīta ar izpratni par zemnieku un sabiedrības nabadzīgo slāṇu izglītošanu. Šì izpratne bija pārmantota no 18. gadsimta, kad tikusi likta vienlìdzības zīme starp latviešiem un zemniekiem, un

\footnotetext{
20 Bergmanis 1824, 3.

21 Limane 1980, 69.

22 Turpat, 68.
} 
tieši apgaismošanas zemnieciskā perspektīva likusi pamatus latviešu literārajai kultūrai. Vienojošs bija arī literārās produkcijas sekulārais raksturs.

\section{Krievijas Bïbeles biedrības Rīgas un Kurzemes nodalas}

Alternatīvu iepriekš aplūkoto biedrību darbībai veidoja 1813. gadā dibinātās Krievijas Bībeles biedrïbas Rìgas un Kurzemes nodaḷas to darbības izvēršana Krievijas impērijā bija Londonas Britu un ārzemju Bībeles biedrības iniciatīva. Biedrības mērḳis bija, vācot ziedojumus gan no augstāko kārtu pārstāvjiem, gan zemniekiem, tirgot vai bez maksas izplatīt Jaunās Derības vai Bībeles eksemplārus, cenšoties panākt, lai Bībele vai Jaunā Derība atrastos katrā mājā. Laikā starp 1813. un 1843. gadu Bībeles biedrības nodaļas izdalīja 40912 Bìbeles un Jaunās Derības eksemplāru. ${ }^{23}$ Īpaši tā pievērsās tieši Svēto Rakstu izplatīšanai latviešu vidū; pēc dzimtbūšanas atcelšanas Karls Gotlobs Zontāgs uzsvēra, ka Bībele ir sevišḳi nepieciešama latviešiem, uzsākot brīvo eksistenci. ${ }^{24}$ Vēl 1855. gadā biedrība aicināja: “Tad nu nestāviet dīkā, mịlie latvieši, kad citi jums par labu strādā; darbojieties ir jūs paši, ka tas Dieva vārds jums papilnam nāktu un bagātus aug̣̣us pie jums nestu. Meklejjiet, ka ikviens jūsu starpā savu Bībeli dabūtu un turētu, un dodiet no savas puses arī labprāt savu dāvanu, lai Bībeles biedrībām netrūktu, ar ko jums to mīlo Dieva vārdu jo lētāki apgādāt. Bet vēl nepietiek to svētu grāmatu tikai pirkt un pie sevim glabāt. Ja tu to, kā daži dara, nelasītu lādē glabāsi, kādus augḷus viṇa tad tevim nesīs? Voi tu nebūsi vīram līdzīgs, kam degoša svece ir, bet viņš to pabāž pūra apakšā, ka tā nevar savu spìdumu izlaist .."25

Ar Britu un ārzemju Bībeles biedrības finansiālu atbalstu 1816. gadā no jauna Bībeles biedrība izdeva Jauno Derību, bet 1825. gadā pilnu Bībeli. Jaunā Derība turpmākajos gados nāca klajā arvien jaunos metienos, sasniedzot daudzu tūkstošu eksemplāru tirāžu. ${ }^{26}$ Bībeles

23 Apīnis 1991, 113, 116.

24 Klepers 1938, 76.

25 [Bez autora] 1852, [2].

26 Apīnis 1991, 101; Apīnis 1977, 112. biedrības Rīgas un Kurzemes nodal̦as izvērsa aktīvu darbỉbu arī reǵionos, dibinot palīgbiedrības Apukalnā, Dzērbenē un Drustos, Cēsīs un Āraišos, Limbažos un Umurgā, Palsmanē un Aumeisteros, Ropažos, Allažos un Vangažos, Smiltenē un citviet. ${ }^{27}$ Visaktīvākā bija Straupes un Raunas Bībeles palīgbiedrība, kura ne tikai izplatīja Svētos Rakstus un vāca ziedojumus, bet arī izdeva hernhūtiešu kustībai radniecīgas grāmatas ar Jaunās Derības izvilkumiem vai pārstāstiem, kā arī garīgajām dziesmām. Ir saglabājušās liecības, ka šîs grāmatas lietoja ne tikai tradicionālās luterānisma draudzes, bet arī hernhūtieši. ${ }^{28}$

Šo biedrību darbības nozīme latviešu grāmatniecībā ir saistāma ne tikai ar latviešu grāmatu izdošanu, bet arī ar jaunu grāmatu izplatīšanas kanālu darbības sekmēšanu, kas bija viens no galvenajiem tautas apgaismìbas mērḳiem kā vācvalodīgajās zemēs, tā Baltijā. Liela nozīme ir ziedojumu vākšanai un grāmatu bezmaksas izplatǐšanai, kas apliecina biedrību filantropisko ievirzi. Minētās biedrības turpina izkopt 18. gadsimta idejisko mantojumu, pievēršoties praktiskai apgaismošanai lauksaimniecībā un medicīnā, kā arī kristīgās reliǵijas izplatīšanai. Taču līdzās šīm tēmām citu biedrību darbībā iezīmējas jau būtiski atškirīga attieksme pret latviešiem - vairs ne kā pret zemnieku kārtu, bet kā nāciju.

\section{Kurzemes Literatūras un mākslas biedrība}

1815. gadā tika dibināta Kurzemes Literatūras un mākslas biedrība (Kurländische Gesellschaft für Literatur und Kunst, turpmāk KLMB), kurai piemita zinātņu akadēmijas ambīcijas un ievirze un kura vēlējās "radīt vietēju forumu aktuālu zinātnisko un sabiedrisko problēmu apspriešanai, veidot tiltu starp austrumiem un rietumiem jeb Krieviju un Vāciju un intelektuāli vienot trīs Baltijas provinces (guberņas), to skaitā Vidzemi un Kurzemi, pirmām kārtām vietējos vāciski runājošos literātus, taču nepiemirstot latviešu cilmes iedzīvotājus, kurus drīzumā bija paredzēts atbrīvot

\footnotetext{
27 Šiško 1999, 466, 644, 298, 444, 467, 472, 615, 484, 493, 298.

28 Turpat, 379.
} 
no dzimtbūšanas. Biedrībā sprieda arī par to, kāda nākotnes perspektīva jāiezīmē brīvajiem latviešiem un igauņiem". ${ }^{29}$

1818. gadā KLMB dibināja Kurzemes Provinces muzeju un bibliotēku. Tās apspriedes bija veltītas dažādiem dabaszinātṇu jautājumiem, biedri iztirzāja tehniskas un matemātiskas problēmas, lauksaimniecỉbas problēmas, geogrāfiskus un meteoroloǵiskus tematus, nozīmīgi bija Teodora Grothusa (Theodor Grotthuß, 1785-1822) pētijumi par "gaismas un elektrības ḳimisko darbību" ${ }^{30}$ Tomēr savā sākuma posmā, neaizmirstot statūtos formulēto, ka "biedrība neaprobežojas, lai tikai izglìtotajās kārtās veicinātu gaumi, mīlestību un kaisli uz augstākām zinībām, [..] kā ìpašu un svētu pienākumu tā uzliek arī no savas puses darboties, lai garīgi paceltu zemākās tautas kārtas", ${ }^{11}$ biedrība "uz îsu laiku kḷuva par letonistikas pirmo publisko tribīni". ${ }^{2}$ Te minami pētijjumi latviešu valodā, etnogrāfijā, senvēsturē, bet galvenokārt interese par latviešu apgaismošanu.

1817. gadā biedrība "plašā apspriedē atzina, ka zināšanas latviešiem jāsniedz religijias apvalkā, ka kalendāru pielikumi jāgādā mācītājiem, ka jāizdod latviešu valodā avīze tautas audzināšanai. Apspriedes atzinumiem bija principiāla un tālejoša nozīme". ${ }^{33}$

1817. gada 8. augustā KLMB Lestenes mācītājs Kārlis Frīdrihs Vatsons (Karl Friedrich Watson, 1777-1826) nolasīja referātu, kurā pieteica latviešu preses izdevuma Mēnešu $A v \bar{i}-$ ze jeb Padomdevējs pie Tās Jaunas Brīvestības Būšanas veidošanu, uzsverot, ka pēc dzimtbūšanas atcelšanas latviešos ir nepieciešams veidot sapratni par politiku, skaidrïbu par jauno stāvokli. Laikrakstam bija paredzētas četras rubrikas: 1) teksti par brīvlaišanas aktualitātēm, jauniem likumiem utt., 2) politiskā informācija par Kurzemi, Krieviju, citām zemēm, 3) atviešu literatūra, ziņas par latviešu grāmatām, 4) rīkojumi, sludinājumi utt. ${ }^{34}$ Vatsons uzsvēra, ka "biedrības statūtos iekḷautie

\footnotetext{
29 Stradinš 2009, 372.

30 Turpat, 377-382.

31 Turpat, 382.

32 Turpat, 383.

33 Apīnis 1977, 111.

34 Zelče 2009, 98-99.
}

augstie mērķi, kuri aptver visu zināšanu kopumu, jāuzskata tikai par ideālu, pēc kā tiekties, jo būtu grūti zinātṇu laukā līdzināties ārzemju zinātniskām biedrībām. Toties biedrībai ir pietiekams spēks darboties tautas izglītībā. [..] Lai gan latvieši izrādot vienaldzību pret labu grāmatu lasī̌anu, viņiem nepavisam netrūkstot intereses par izglītošanos vispār un caur praksi (durch's Leben) arī par politiku. Vēlēšanās uzzināt, kas notiek valstī un citur, savienota ar slēptu vēlmi, kur iespējams, arī kādu vārdiņu līdzi runāt. Šo latviešu politisko interesi .. biedrībai vajadzētu saprast ..."35

1819. gadā biedrība sarīkoja diskusiju par latviešu pārvācošanos, kas ieguvusi apzīmējumu "Jelgavas debates". ${ }^{36}$ Te iezīmējās pāreja no latviešu apgaismošanas caur grāmatām uz brīvu domu apmaiṇu un ideju forumu par latviešu nākotni.

Diskusijā parādījās trīs viedokḷi par latviešu pārvācošanos. Pirmais, kuru pauda mācītāji Ādams Konrādijs (Adam Conradi, 1768-1830), Karls Ludvigs Vilperts (Karl Ludwig Wilpert, 1785-1861) un Johans Georgs Bitners (Johann Georg Büttner, 1779-1862), aizstāvēja latviešu pārvācošanos, pieņemot, ka vācu valoda pavērs latviešiem cel̦u uz izglìtību, ka, aizejot bojā latviešu valodai, nenostiprināsies arī latviešu nacionalitāte, kuras tāpat nav sevišḳi daudz, ja ṇem vērā līdzšinējo apspiešanu, tiktu nodibinātas netraucētas attiecības starp pilsoņiem un iegūts drošs izglìtības līdzeklis latviešiem: "Latvieši savu tautību tā kā tā neuzturēs, viṇi paliks vai nu par krieviem, vai vāciešiem. Pēc mūsu ticības, kā ari mūsu izglītības mūsu pienākums ir, viņus saistìt sev klāt. Ar to tad reiz būtu iznīcināta līdzšinējā plaisa starp vāciešiem un latviešiem, starp kungiem un tautu." ${ }^{37}$ Pretstatā šim iezīmējams otrs viedoklis, kuru pauda filozofijas doktors un antīkās senatnes pētnieks Ernsts Trautfeters (Ernst Trautvetter, 1780-1859), jurists Georgs Benedikts Engelharts (Georg Benedict Engelhardt, 1760-1822), advokāts un apriņķa maršals Gerhards Kristofs Georgs fon den Brinkens (Gerhard Christoph Georg von den Brincken, 1775-1836) un kurš balstīts bažās, ka latviešu pārvācošanās, t. i.,

\footnotetext{
35 Vanaga 2000, 195.

36 [Bienemann] 1905, 61-71; Šķiņķe 1996, 85-90.

37 Ārons 1929, 69-70.
} 
vācu valodas apguves piedāvājums latviešiem, apdraudēs pašu vāciešu dominējošo lomu Baltijā: "Vācu valoda ir izglîtoto, bet latviešu - zemnieku valoda, šādi arī veidojamas abu valodu turpmākās attiecības." ${ }^{38}$

Trešais viedoklis piedāvāja raudzīties uz latviešu valodu kā pašvērtību. Kārlis Frīdrihs Vatsons deklarēja, ka valoda ir "nacionalitātes sargātāja”, ka latviešu valoda "ir jāstudē un pilnībā jāapgūst, lai pārliecinātos, ka tā nekādā ziṇā nav nabadzīga un barbariska, bet gan bagāta un lokana, un baznīcas jomā jau attīstīta, tātad juridiskā un politiskā jomā ir tikpat spējīga uz attīstību" ${ }^{39}$ Viṇa norāde uz latviešu valodu kā patieso Kurzemes valodu, kurai ir potenciāls arī politiskajā sfērā, faktiski pavēra cel̦u uz pavisam jaunu izpratni par latviešiem - kā par potenciālu kultūrnāciju, kas būtu līdzvērtīga vāciešiem, nevis kā par tautu, kuras profesija ir zemkopỉba. Šì izpratne bija radniecīga Johana Gotfrīda Herdera (Johann Gottfried Herder, 1744-1803) tēzei: "Nevar nodarìt lielāku zaudējumu kādai nācijai, kā viņai nolaupot tās nacionālo raksturu, tās gara savdabību un viṇas valodu." ${ }^{40}$ Lìdzīgi izteicās profesors Karls Vilhelms Krūze (Karl Wilhelm Cruse, 1765-1834), aizstāvēdams latviešu valodas saglabāšanu: "Vinu kā brīvu cilvēku vajadzībām latviešu valoda vairs nav pietiekama - tā jāattīsta. Lìdz šim valodu ir attīstīijis vācu gars. Nepieciešamība no vergu valodas veidot brīvu cilvēku valodu [..] [risināma] caur skolām, kurās latviešiem gan tiktu mācìta latviešu valoda, bet vienlaikus būtu iespēja apgūt vācu valodu." ${ }^{41}$ Mācītājs Karls Johans Elferfelds (Karl Johann Elverfeld, 1781-1851) balstijās "viedoklī, ka liegt latvietim runāt latviski nozīmē liegt viṇam eksistēt, kas arī nekaitētu tiktāl, ciktāl šì eksistence būtu nosodāma savu slikto îpašỉbu dēḷ. Tā kā tomēr latvietim neviens neko absolūti sliktu nevar pārmest, viṇa tautiskums turpretī ir labs un caur iegūto brīvību kḷūs izcils, neviens nedrīkst un nevar iecerēt pret viṇu garīgu slepkavību!". ${ }^{42}$

\footnotetext{
38 Trautvetter 1822, 18.

39 Watson 1822, 19-20.

40 Citēts pēc: Šk̦iņķe 1996, 83.

41 Cruse 1822, 17.

42 Elverfeld 1822, 21-22.
}

Viens no svarīgākajiem biedrības apspriežu rezultātiem bija ideja par pirmā latviešu laikraksta Latviešu Avizes izdošanu. Kaut gan izdošanas tiesības nenokḷuva KLMB monopolā, tās redakcija atrodas KLMB telpās un laikraksta attīstìba norisinās ciešā sadarbībā ar KLMB aktivitātēm. ${ }^{43}$

\section{Latviešu literārā (draugu) biedrība}

Jau KLMB diskusijās iezīmējās ideja par nepieciešamību pievērst padziḷinātu uzmanību ne tikai vispārderīgiem humāniem reformu plāniem, bet konkrēti latviešu valodai un kultūrai. Par šĩs intereses aizmetñiem liecina 1811. gadā dibinātā neformālā Latviešu biedrība, par kuras darbību saglabājies maz ziṇu un kura pastāvēja vien dažus gadus. Tā izveidota, luterāṇu baznīcas konventā Cēsīs izskanot idejai par latviešu valodai veltìtu apcerējumu nolasǐšanu turpmākajos konventos, - šì iecere pārauga īpašas biedrības izveidē, par kuras vadītāju kḷuva Rubenes mācītājs Kristofs Harders (Christoph Harder, 1747-1818) un kura savus rakstus par latviešu valodu vispirms iesūtīja vadītājam, bet tas pēc tam ar savām piezīmēm tos izsūtīja tālāk citiem. ${ }^{44}$ Biedrības loceklis Kristofs Reinholds Girgensons (Christoph Reinhold Girgensohn, 1752-1814) 1813. gadā formulēja divus cel̦us, "kādam jābūt biedrības mērḳim, lai tas kḷūtu sabiedrībai derīgs, un kā to sasniegt", - "vienu uz latviešu valodas apmācīšanu un bagātināšanu, otru uz nācijas apgaismi un izglìtošanu, dodot latviešu rokās pamācošus un izklaidējošus sacerējumus"." ${ }^{5}$

No 1819. gada gadskārtējos mācītāju konventos par tradīciju kḷuva latviešu kultūras jautājumu apspriešana - līdzās tādām tēmām kā latviešu gramatika un tautasdziesmas tika prezentētas esejas Vai iespējams un ir derīgi apspriest latviešu valodu?, Par latviešu tautību, Kā vislētākā kārtā ierīkojami skolotāju semināri? u. c. ${ }^{46}$ Šajā laikā "ik pa laikam uzvirmoja domas par latviešu literārās valodas kopēju un lietotāju iespējamiem sadarbības ceḷiem: bija jūtama pieaugoša vajadzība pēc apvienošanās

\footnotetext{
43 Stradinš 2009, 385.

44 Švābe 1958, 64.

45 Frīde 2011, 89.

46 Ārons 1929, 108.
} 
jaunu ideju realizēšanai, lai varētu koordinēt, sekmēt un virzìt ne tikai latviešu valodas pētīšanu un studēšanu, bet arī rakstīt un publicēt savus darbus. Turklāt ne tikai literātiem, bet arī pārējiem interesentiem un latviešu tautas attīstības veicinātājiem bija vajadzīgs centrs, kura ietvaros organizēt priekšlasījumus un disputus". ${ }^{47}$

Šīs ieceres īstenojās Latviešu literārā (drau$\mathrm{gu})$ biedrībā (Lettisch-literärische Gesellschaft, turpmāk - LLDB), kas dibināta 1824. gadā un ko valdība apstiprinājusi 1827. gadā. Arī to veidoja vācbaltiešu mācītāji pēc Karla Gotloba Zontāga iniciatīvas, un tā primāri bija iecerēta latviešu valodas izpētei. Valodas izpēte un emancipācija tomēr nekḷuva par biedrības vienīgo uzmanības objektu. Biedrïbas locekḷi izstrādāja nozīmīgus pētījumus vēsturē, etnogrāfijā, folkloristikā (tostarp publicējot plašus folkloras vākumus), vārdnīcu izstrādē. Kaut arī biedrība tika uztverta un arī pati sevi apzinājās kā vācu biedrību, nav noliedzams, ka tā "varēja nākt un nāca bez šaubām aplinkus un arī tieši latviešiem par labu"48 un ka "daudzi vācu tautības mācītāji bija patiesi un sirsnīgi latviešu tautas draugi jeb letofili .. viņu devums latviešu tautai un arī letonistikas attīstībai ir neapšaubāms". ${ }^{49}$

Biedrïba izdeva savu periodisko izdevumu Magazin, kurā tika publicēti apcerējumi par valodniecību, etnogrāfiju, folkloru, kā arī daiḷiteratūras darbi latviešu valodā; kaut gan pamatā periodiskais izdevums bija paredzēts vācbaltiešu auditorijai, samērā regulāri iznā-

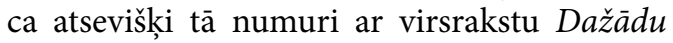
rakstu krājums, kas domāti latviešu lasītājiem. Literatūras vēstures aspektā šie daillliteratūras darbi ir svarīgi, jo balstījās idejā par latviešu valodas poētisko iespēju pārbaudišanu - tie galvenokārt bija tulkojumi, kas iezīmēja svarīgu pavērsiena punktu latviešu literārajā kultūrā, proti, pāreju no zemniekiem adresētas daiḷiteratūras uz eksperimentiem ar "augsto literatūru”, galvenokārt sacerējumiem heksametrā, kā arī Veimāras klasikas dzejas darbu tulkojumiem.

\footnotetext{
47 Frīde 2011, 90.

48 Ārons 1929, 120.

49 Stradiņš 2009, 508.
}

Te īpaši izcelami Dionīsija Gotfrīda Krona (Dionysius Gottfried Croon, 1779-1838) veiktie Frīdriha Gotliba Klopštoka (Friedrich Gottlieb Klopstock, 1724-1803) Der Messias fragmentu atdzejojumi 1828. gadā un Johana Volfganga fon Gētes (Johann Wolfgang von Goethe, 1749-1832) dzejol,a Fischer atdzejojums 1830. gadā, Johana Gotfrīda Ageluta veiktie Johana Heinriha Fosa (Johann Heinrich Vo $\beta, 1751-1826)$ heksametros sacerēto idillıu atdzejojumi 1828 gadā. Zīmīgs un simbolisks bija 1829. gadā izdevumā Magazin publicētais Frīdriha Šillera (Friedrich Schiller, 1759-1805) balādes Burgschaft atdzejojums trīs tulkotāju versijās - paralēli iespiests vācu mācītāju Kārḷa Hūgenbergera (Karl Hugenberger, 1784-1860) un Jākoba Florentīna Lundberga (Jakob Florentin Lundberg, 1782-1858), kā arī latviešu skolotāja M. Aumaņa tulkojums. ${ }^{50}$ Vērtējot izdevumā Magazin publicētos darbus, Garlībs Merḳelis (Garlieb Merkel, 1769-1850) rakstīja: "No burtnīcas skaidri redzams, kādi aug̣̣i sagaidāmi no Latviešu Literariskās Biedrības darbības. Tagad rakstu sagādāšana latviešu valodā atrodas vienīgi mācìtu vāciešu rokās. Pēc trim, lielākais 4 gadu desmitiem tas vairs tā nebūs, tad latviešu tautības rakstnieki saṇems no šìs ḷoti cienījamās biedrības savu valodu jau kā labi izkoptu ieroci. Kaut tā nenogurtu savā cēlā darbībā!"’sı

Šie darbi liecināja par sacensības garu un popularitāti, kuru latviski rakstošo vācu mācītāju vidū guva augstās literatūras tulkošana. Tā bija liecîba literatūras elitarizācijai - kaut gan latvieši netika izslēgti no šo tulkojumu lasītāju loka, to primārā auditorija tomēr ir vācu elites pārstāvji. Tikmēr laikabiedri pauda bažas, vai latviešu zemniekiem šādi tulkojumi būs saprotami un piemēroti. ${ }^{52}$ Tam biedrība piedāvāja vairākus pretargumentus. Pirmkārt, tā balstījās viedoklī, ka "[k]atras tautas valoda ir pasargājama no iznīcības. Protams, tā bija visas tālaika Eiropas garīgās dzīves tendence arī citas tautas veidoja un stiprināja nacionālo pašapziṇu, tomēr pirmsākumos tas bija vāciskās kultūrtelpas latviešu literātu apzināts solis, kuriem rūpēja tautas liktenis un kuri negribēja

\footnotetext{
50 Klekere 2009, 88-94.

51 Ārons 1929, 120.

$52 \mathrm{M}$ [erkel] 1828, 18.
} 
piel̦aut, lai zudībā iet, vinuuprāt, sena un skanìga valoda". ${ }^{3}$ Otrkārt, kā to deklarēja viens no biedrïbas locekliem, "[m]ums citas svešas valodas nevajaga, jo mēs redzam, ka mēs ar savu pašu varam iztikt un pārtikt ne vien pie māju, lauku, lopu kopšanas, bet arīdzan visur un katrā būšanā, kur svēta apdoma un gudrības vajaga, kur prāts uz neredzamām garīgām lietām un augstām svētām domām cilājas!" ${ }^{4}$

Šie uzskati un biedrības aktivitātes izauga no Kristofa Reinholda Girgensona formulētā pretstata starp tautas apgaismošanu un valodas izkopšanu. Tieši ar dzimtbūšanas atcelšanu saistītais patoss par latviešu nākotni sekmēja ideju par latviešu valodas un literatūras emancipāciju, atbrīvošanu no zemnieku literatūras šaurajiem ietvariem, piemērojot tai vispārcilvēciskus kritērijus un uzlūkojot to kā potenciālu kultūrnācijas valodu. Tādējādi tika likti pamati vēlākajai latviešu nacionālajai atmodai.

\section{Nobeigums}

Biedrības dažādos veidos turpināja kopt apgaismības laikmeta idejas. Lielā mērā tieši biedrību darbībā vislabāk redzama kontinuitāte starp 18. gadsimta idejisko mantojumu un apgaismības turpinājumu 19. gadsimtā. Biedrību mērḳi bija dažădi, lielākoties saistīti ar patriotiskām reformām un vispārderīgumu, taču simptomātiski, ka šajos mērḳos stabilu vietu atrada latviešu grāmatu izdošana, nereti

53 Frīde 2011, 107.

${ }^{54}$ Citēts pēc: Frīde 2011, 107. latviešu literatūras veicināšanu paredzot kā tikai vienu, dažkārt pat marginālu, tomēr nepieciešamu posmu to daudzveidigajā darbībā. Tādējādi var apgalvot, ka 19. gadsimta pirmajā pusē latviešu grāmatniecība līdztekus individuāliem darbiem veidojās kā daḷa no vērienīgākiem reformu projektiem, vienalga, vai tie būtu saistīti ar lauksaimniecības reformām, nabadzības izskaušanu, politiskām reformām vai akadēmiskiem pētijjumiem. Raugoties no latviešu literatūras vēstures skatpunkta, biedrību loma tās veicināšanā ir ievērojama, īpaši ņemot vērā biedrību aktivitātes izdevumu bezmaksas izplatīšanā un jaunu žanru izkopšanā. Biedrību aktivitātes atklāj, no kādiem daudzveidīgiem un bieži ar literatūru tieši nesaistītiem avotiem veidojas latviešu grāmatniecība, kā īstenojas pāreja no praktiski ekonomiskās un medicīniskās literatūras uz latviešu daiḷliteratūru. Vēl vairāk - tā atklāj arī, ka šajā posmā latviešu literatūra bija daļa no plašāka sabiedrības modernizācijas procesa, kas ietvēra dažādas aktivitātes.

Biedrības darbojās dažādos virzienos - ne tikai kā latviešu grāmatu izdevējas un izplatītājas, bet arī kā ideju forumi, kuros ar laiku tieši jautājumi par latviešu identitāti un nākotni nonāca uzmanības centrā. Izsekojot vācbaltiešu biedrību darbībai, ir redzams, kā attieksme pret latviešiem un zemtekstā arī pret latviešu grāmatniecību pakāpeniski mainījās no izpratnes par latviešiem kā zemniekiem lìdz priekšstatam par latviešiem kā nāciju, arī - potenciālu kultūrnāciju, kas lika pamatus vēlākajai jaunlatviešu kustībai.

\section{VĒRES}

[Bez autora] (1852) Ziņas par Kurzemes Bībeles biedrību. Jelgava : J. F. Stefenhāgens un dēls.

[Bienemann, F.] (1905) Sieben Vorträge über Germanisierung der Letten: Eine Reminiszenz vom J. 1819. Baltische Monatsschrift, 1, 61-71.

Apīnis, A. (1977) Latviešu grāmatniecība: no pirmsākumiem līdz 19. gadsimta beigām. Rīga : Liesma.

Apīnis, A. (1991) Grāmata un latviešu sabiedrība lìdz 19. gadsimta vidum. Rīga : Liesma.

Ārons, M. (1929) Latviešu literariskā (latviešu draugu) biedrība savā simts gadu darbā: ainas no vāciešu un latviešu attiecību vēstures. Rīga : A. Gulbis.

Bergmanis, D. G. (1824) Augsti apstiprināti likumi priekš krāšanas šķirsta Rīgēe. Rīga : V. F. Hekers.

Bulmerincq, A. (1852) Geschichte der allerhöchst bestätigten literärisch-praktischen Bürger-Verbindung zu Riga. Riga : W. F. Häcker.

Cruse, K. W. (1822) Einige Worter über demselben Gegenstand. Jahresverhandlungen der Kurländischen Gesellschaft für Literatur und Kunst. Band II. Mitau : J. F. Steffenhagen und Sohn, 17. 
Daija, P. (2016) Mālpils mācītājs Johans Gotfrīds Ageluts latviešu laicīgās literatūras vēsturē. Pauloviča, I. (sast.) Kultūrvēstures avoti un Mālpils novads. Mālpils : Mālpils novada dome, 84-100.

Elverfeld, K. (1822) Für die Erhaltung der lettischen Sprache. Jahresverhandlungen der Kurländischen Gesellschaft für Literatur und Kunst. Band II. Mitau : J. F. Steffenhagen und Sohn, 21-22.

Engelhardt, H. D.; Neuschäffer, H. (1983) Die Livländische gemeinnützige und ökonomische Sozietät (17921939). Ein Beitrag zur Agrargeschichte des Ostseeraums. Köln/Wien : Böchlau.

Frīde, Z. (2011) Ienest sveci istabā. Latviešu literatūras veidošanās aspekti 19. gadsimta pirmajā pusēe Rīga : LU LFMI.

Hackmann, J. (2012) Vereinskultur und Zivilgesellschaft in Nordosteuropa: lokal, national, regional, europäisch oder global? Hackmann, J. (Hg.) Vereinskultur und Zivilgesellschaft in Nordoseuropa: Regionale Spezifik und europäische Zusammenhänge. Wien/Köln/Weimar : Böhlau Verlag, 11-36.

Hollander, B. (1927) Geschichte der Literärisch-praktischen Bürgerverbindung in Riga: 1802-1927. Riga : E. Plates.

Klekere, I. (2009) Dzejas publikācijas Latviešu literārās biedrības krājumā "Magazinnas": 1828-1855. Latvijas Nacionālās bibliotēkas Zinātniskie raksti, 1, 88-94.

Klepers, Ā. (1938) G̦enerālsuperintendents Kārlis Gottlobs Zonntags kā izglìtības darbinieks. Rīga : Grāmatrūpnieks.

Kopitzsch, F. (2003) Aufklärung. Van Dülmen, R. (Hg.) Das Fischer Lexikon. Geschichte. Frankfurt am Main : Fischer Taschenbuch Verlag, 139-149.

Limane, L. (1980) Latviešu pretalkoholisma literatūra 19. gadsimta pirmajā pusē. Bibliotēku zinātnes aspekti. Grāmata - lasìtājs. Nr. 4 (IX). Rīga : Avots, 63-81.

M[erkel, G]. (1828) Lettische Literatur. Literärischer Begleiter des Provinzialblattes, 5, 18.

Pīrāgs, V. (2008) Brīvmūrnieku rituālu izcelsme Latvijā. Akadēmiskā Dzīve, 45, 68-79.

Reinalter, H. (1995) Gesellschaften, patriotische. Schneiders, W. (Hg.) Lexikon der Aufklärung: Deutschland und Europa. München: C. H. Beck, 158-160.

Stradiṇš, J. (2009) Zinātnes un augstskolu sākotne Latvijā. Rīga : Latvijas vēstures institūta apgāds.

Strods, H. (1962) Lauksaimniecības biedrību darbība Latvijā feodālisma sairšanas periodā (18. gs. beigās 19. gs. 60. gadu sākumā). Zutis, J. (atb. red.) Vēstures problēmas. 5. sēj. Rìga : LPSR ZA, 71-110.

Strods, H. (1972) Lauksaimniecība Latvijā pārejas periodā no feodālisma uz kapitālismu (18. gs. 80. gadi -19. gs. 60. gadu sākums). Rīga : Zinātne.

Šiško, S. (1999) Seniespiedumi latviešu valodā, 1525-1855: kopkatalogs. Izstrādājis aut. kol. Silvijas Šiško vadībā; zin. red. Aleksejs Apīnis. Rīga : Latvijas Nacionālā bibliotēka.

Šḳiņķe, I. (1996) Kurzemes Literatūras un mākslas biedrība un latviešu valodas attīstības jautājums 19. gadsimta 1. pusē. Latvijas Arhìvi, 3/4, 85-90.

Švābe, A. (1958) Kāda mācītāja dzīve. Stokholma : Daugava.

Trautvetter, E. C. (1822) Über das Sprachverhältni $\beta$ im deutschen Ostseelande. Jahresverhandlungen der Kurländischen Gesellschaft für Literatur und Kunst. Band II. Mitau : J. F. Steffenhagen und Sohn, 17-19.

Vanaga, L. (2000) K. F. Vatsons (1777-1826) Kurzemei un latviešiem. Arheologiija un Etnogräfija, 20, 192-207.

Watson, K. F. (1822) Ueber denselben Gegenstand. Jahresverhandlungen der Kurländischen Gesellschaft für Literatur und Kunst. Band II. Mitau : J. F. Steffenhagen und Sohn, 19-21.

Zelče, V. (2009) Latviešu avīžniecība: laikraksti savā laikmetā un sabiedrībā, 1822-1865. Rīga : Zinātne. 